\title{
PROBLEMATYKA PRAWNA „POŚWIADCZONEGO ODPISU" W ZAWODZIE TŁUMACZA PRZYSIĘGŁEGO - UWAGI DE LEGE LATA I DE LEGE FERENDA
}

\author{
Katarzyna LITWIN ${ }^{77}$, mgr $^{78}$ \\ Katedra Prawa Karnego, Instytut Wymiaru Sprawiedliwości \\ Krakowska Akademia im. Andrzeja Frycza Modrzewskiego \\ ul. Żeromskiego 5/8, Rzeszów \\ thumacz@ litwin.rzeszow.pl \\ Kamil SZPYT \\ Wydział Prawa i Administracji, Uniwersytet Rzeszowski
}

\begin{abstract}
Abstrakt: Opracowanie porusza kwestię bardzo problemową w zawodzie tłumacza przysiegłego uregulowanie prawne, interpretację oraz stosowanie uprawnienia do ,sporządzania poświadczonych odpisów pism w języku obcym, sprawdzania i poświadczania odpisów pism, sporządzonych w danym języku obcym przez inne osoby" przez tłumaczy przysięłych w Polsce. Po wprowadzeniu historycznym, przedstawiającym źródła współczesnych uregulowań tego zagadnienia, przedstawiono pojęcie „poświadczonego odpisu” w innych aktach prawnych w celu odszukania zarówno jego pierwotnego, jak i współczesnego znaczenia. Następnie porównano „poświadczony odpis” w zawodzie tłumacza przysiegłego na podstawie Ustawy o zawodzie tłumacza przysiegłego i Rozporządzenia Ministra Sprawiedliwości w sprawie wynagrodzenia za czynności tłumacza przysiegłego oraz notariusza na podstawie Ustawy prawo o notariacie i Rozporządzenia Ministra Sprawiedliwości w sprawie maksymalnych stawek taksy notarialnej. Szeroko omówiono kwestie problematyczne dla tłumaczy przysięłych oraz propozycje zmian i wnioski końcowe.
\end{abstract}

\section{LEGAL PROBLEMS REGARDING 'CERTIFIED COPY' IN PROFESSION OF CERTIFIED TRANSLATORS - DE LEGE LATA AND DE LEGE FERENDA}

\begin{abstract}
This paper presents a problematical issue regarding the right of a legal translator to „execute certified copies of documents drawn up in a foreign language, verify and certify copies of documents drawn up in a foreign language and prepared by another person". After a brief commentary concerning the development of the institution and the sources of this right in other

\footnotetext{
77 Autorka jest uczestniczką seminarium doktorskiego w Katedrze Prawa Karnego Instytutu Wymiaru Sprawiedliwości Krakowskiej Akademii im. Andrzeja Frycza Modrzewskiego i tłumaczem przysięgłym języka ukraińskiego (TP/636/07) oraz członkiem nadzwyczajnym TEPIS. Zdobyte doświadczenie na stanowisku asystentki notariusza w jednej z rzeszowskich kancelarii notarialnych stało się przyczynkiem poszukiwania rozwiązań omawianej problematyki w regulacjach dotyczących notariatu.

${ }^{78}$ Autor jest studentem IV roku prawa na Wydziale Prawa i Administracji Uniwersytetu Rzeszowskiego, Prezesem Koła Naukowego Prawa Mediów, uczestnikiem i laureatem licznych konkursów prawniczych.
} 
modern regulations, the meaning of the term 'certified copy' is discussed in the light of other binding legal acts. The term 'certified copy' used in relation to the profession of a certified translator under the Act on the profession of certified translators and the Regulation of the Minister of Justice on certified translators' fee, and profession of a notary in the Act on Notary Public Law and the Regulation of the Minister of Justice on the maximum notaril fee are discussed. Finally, recommendations concerning proposed legislative changes and conclusions are presented.

\section{Wstęp}

Stosowanie pojęcia ,poświadczonego odpisu” budzi wątpliwości tłumaczy przysięgłych w Polsce od wielu lat, ale regulacje wprowadzone przez Ustawę z dnia 25 listopada 2004 r. o zawodzie tłumacza przysięłłego (Dz.U.04.273.2702) uczyniły tę kwestię jeszcze bardziej problematyczną. Akt ten nadaje bowiem tłumaczom przysięgłym uprawnienia sporządzania poświadczonych odpisów pism w języku obcym, sprawdzania i poświadczania odpisów pism, sporządzonych w języku obcym przez inne osoby - uprawnienia wykonywane również przez notariuszy. Dlatego wątpliwe są motywy, jakimi kierował się ustawodawca wprowadzając w życie w dniu 27 stycznia 2005 roku wspomnianą ustawę oraz akty wykonawcze do niej. Zasadnym jest więc rozpoczęcie analizy problematyki ,poświadczonego odpisu” od historii tego pojęcia w regulacjach dotyczących zawodu tłumacza przysięgłego $\mathrm{w}$ celu odszukania źródła obecnie obowiązujących przepisów.

\section{Rys historyczny}

Do ustawodawstwa polskiego pojęcie tłumacza zostało wprowadzone wraz z przyjęciem w dniu 7 sierpnia 1920 roku Rozporządzenia Ministra Sprawiedliwości w porozumieniu z Ministrem Skarbu Państwa (Dz. U. Nr 75, poz. 515), które dotyczyło wynagrodzenia tłumaczy w postępowaniu karnym. Rozporządzenie to nie przewidywało jednak wynagrodzenia za sporządzenie odpisu, a jedynie za tłumaczenia ustne i pisemne $(\S 19$ i $§$ 20). Tymczasem pojęcie ,odpisu” funkcjonowało już w języku polskim od wielu lat. W Słowniku jezzyka polskiego, wydanym w Warszawie w 1903 roku pod redakcja J. Karłowicza, A. Kryńskiego i W. Niedźwiedzkiego pojęcie odpisu wyjaśniono jako „kopja odpisana z czego"79, ponieważ odpisy były w owych czasach „odpisywane” ręcznie. W takim też znaczeniu pojawiło się ono w kolejnym akcie prawnym dotyczącym tłumaczy - w 1928 roku ukazało się Rozporządzenie Ministra Sprawiedliwości z dnia 24 grudnia 1928 r. o tłumaczach przysięgłych (Dz. U. Nr 104, poz. 943), w którym w $\$ 10$ przewidziano, że tłumacz przysięgły winien prowadzić repertorium wszystkich sporządzonych przez niego lub sprawdzonych „tłumaczeń lub odpisów”. Zrozumiałe jest zatem, że w owych czasach tłumacze sporządzali już odpisy pism. Przepis ten stał się zatem źródłem późniejszych uregulowań prawa do sporządzania poświadczonych odpisów pism przez tłumaczy przysięgłych. Słowo to zostało użyte w również $\S 11,(\ldots)$ na przekładach winno być zamieszczone zaświadczenie, czy tłumaczenia dokonano z oryginału, czy też z przekładu lub z odpisu, a w ostatnim wypadku, czy odpis jest uwierzytelniony i w jaki sposób”. Paragraf 11 wymienionego aktu stał się pierwowzorem współczesnego art. 18 Ustawy o zawodzie tłumacza przysięgłego, stanowiącego w ustępie 2 , że „(...) Na sporządzonych tłumaczeniach i odpisach pism należy stwierdzić, czy sporządzono je z oryginału, czy też z tłumaczenia lub odpisu, oraz czy tłumaczenie lub odpis jest poświadczony i przez kogo”. Akty prawne,

\footnotetext{
${ }^{79}$ Karłowicz J., Kryński A., Niedźwiedzki W. (red.), Stownik języka polskiego, Warszawa 1904, 636.
} 
dotyczące zawodu tłumacza przysięgłego, które weszły w życie w roku 1930 wciąż nie regulowały kwestii uprawnień tłumacza - wynagrodzenie ,za czynności tłumacza przysięgłego", w granicach przewidzianych przez prawo, ustalał odpowiedni sąd. Wprost nadano tłumaczowi przysięgłemu uprawnienia sporządzania poświadczonych odpisów pism Rozporządzeniem Ministra Sprawiedliwości z dnia 19 sierpnia 1968 roku w sprawie tłumaczy przysięgłych (Dz. U. Nr 35, poz. 244). Rozporządzenie to przewidywało spis uprawnień tłumacza przysięgłego, wśród których w $\$ 7$ pkt. 2 wskazano, że jest on uprawniony do ,sporządzania zaświadczonych odpisów pism w języku, dla którego został ustanowiony, a także do sprawdzania i zaświadczania odpisów pism sporządzonych przez inne osoby”. Ten właśnie przepis - $§ 7$ stał się pierwowzorem dla współczesnego uregulowania uprawnień tłumacza przysięgłego w Ustawie o zawodzie tłumacza przysięgłego. W $\S 13$ tegoż rozporządzenia ustawodawca zaznacza, że „,na wszystkich zaświadczonych tłumaczeniach oraz zaświadczonych odpisach pism sporządzonych w języku obcym, które wydaje tłumacz przysięgły ( $\$ 7$ ust. 1 i 2), powinna być wymieniona pozycja, pod którą tłumaczenie lub odpis pisma sporządzonego w języku obcym zapisane są w repertorium, oraz podana wysokość pobranego wynagrodzenia. Ponadto na sporządzonych tłumaczeniach i odpisach pism należy stwierdzić, czy sporządzono je $\mathrm{z}$ oryginału, czy też $\mathrm{z}$ tłumaczenia lub odpisu, a w ostatnim wypadku, czy tłumaczenie lub odpis jest zaświadczony i przez kogo". W ust. 2 tegoż paragrafu, ustawodawca zaznacza również, że ,jeżeli pismo, które zostało przetłumaczone lub którego odpis sporządzono, zawiera cechy nasuwające wątpliwości co do rzeczywistej jego treści (np. zawiera ślady przeróbek), należy uczynić o tym wzmiankę na tłumaczeniu lub odpisie pisma, które wydaje tłumacz". W Małym słowniku języka polskiego wydanym w tym samym roku w Warszawie pod redakcją S. Skorupki, H. Anderskiej i Z. Łempijskiej pod hasłem „odpis” odnajdujemy wyjaśnienie: „tekst odpisany, kopia oryginału" " W momencie wejścia W życie wspomnianego rozporządzenia „odpis” miał więc postać odpisanego ręcznie lub też na maszynie dokumentu i miał na celu odzwierciedlenie treści oryginału. Inne elementy, jak np. zmiany, poprawki, znaki graficzne (np. godła państwowego) wymagały ich dokładnego opisu. Uprawnienia te, należące od wieków do notariuszy, zostały przyporządkowane tłumaczowi przysięgłemu $\mathrm{z}$ uwagi na brak znajomości języka obcego przez notariuszy oraz braku odpowiednich narzędzi, a co za tym idzie niemożności „odpisania" dokumentu sporządzonego w języku obcym. Nawet poświadczenie przez notariusza odpisu pisma w języku obcym sporządzonego przez inną osobę władającą językiem obcym i alfabetem języka obcego, było niemożliwe z powodu niemożności starannego porównania przez notariusza „odpisanego" dokumentu z dokumentem oryginalnym sporządzonym w języku obcym, a tym samym należytego poświadczenia odpisu. Ryzyko niezauważenia drobnych, a istotnych zmian, w szczególności w zakresie języków posługujących się alfabetem innym niż łaciński, przeczyło istocie poświadczania odpisu „za zgodność z oryginałem”. Nadanie uprawnień do sporządzania zaświadczonych odpisów pism tłumaczowi przysięgłemu w języku, dla którego został on ustanowiony,

${ }^{80}$ Skorupka S., Anderska H., Łempijska Z. (red.), Mały stownik języka polskiego, Warszawa 1968429. 
a także do sprawdzania i zaświadczania odpisów pism sporządzonych przez inne osoby było więc w owym czasie w pełni uzasadnione.

Niedługo potem, w latach siedemdziesiątych XX wieku, w Polsce zaczęły pojawiać się pierwsze modele kopiarek $^{81}$, które w błyskawicznym tempie zaczęły wypierać wcześniejsze kosztowne i czasochłonne metody „sporządzania odpisów”. Posiadający je notariusze zaczęli kopiować i poświadczać odpisy dokumentów sporządzonych w językach obcych bez udziału tłumacza przysięgłego. Uprawnienie do czynności sporządzania poświadczonych odpisów pism w języku obcym, sprawdzania i poświadczania odpisów pism, sporządzonych w danym języku obcym przez inne osoby było wykonywane zatem równocześnie przez tłumaczy przysięgłych jak i przez notariuszy.

W kolejnych aktach prawnych, które poprzedzały pierwszą i obecnie obowiązująca ustawę o zawodzie tłumacza przysięgłego, słowo „odpis” zostało użyte wielokrotnie $^{82}$. W art. 21 Rozporządzenie Ministra Sprawiedliwości z 8 czerwca 1987 roku w sprawie biegłych sądowych i tłumaczy przysięgłych (Dz. U. Nr 18, poz. 112) powielono (z dostosowaniem terminologii do ówczesnego języka ${ }^{83}$ ) § 7 Rozporządzenia Z dnia 19 sierpnia 1968 roku, przewidujący spis uprawnień tłumacza przysięgłego; podobne brzmienie zachował również $\S 13$ pkt. 1 i $2^{84}$ tegoż rozporządzenia.

\section{„Odpis” we współczesnym prawie polskim}

Zarówno ustawa o zawodzie tłumacza przysięgłego, jak i akty wykonawcze do niej nie zawierają pojęcia „odpisu”. Nie zawiera go również Kodeks tłumacza przysięgłego dokument uchwalony przez Radę Naczelną Polskiego Towarzystwa Tłumaczy Ekonomicznych, Prawniczych i Sądowych „TEPIS ${ }^{\not 85}$ zawierający wytyczne i wskazówki w zakresie wykonywania zawodu tłumacza przysięgłego. Jednocześnie w innych aktach prawa krajowego nie znajdujemy jego prawnej definicji czy stawianych mu wymagań, mimo, iż pojęcia tego ustawodawca używa wielokrotnie, głównie w prawie procesowym. Dlatego też interpretacja tego terminu powoduje liczne trudności nie tylko w stosowaniu regulacji dotyczących zawodu tłumacza przysięgłego. W związku z powyższym Sąd Najwyższy wydał Postanowienie z dnia 27 stycznia 2006 roku III CK 369/05 (Orzecznictwo Sądu Najwyższego Izba Cywilna 2006/11/187) określając odpisem „dokument wiernie odzwierciedlający treść oryginału orzeczenia albo jego kopię”. Jak

\footnotetext{
${ }^{81} \mathrm{http} / / /$ pl.wikipedia.org/wiki/Kserokopiarka, 01.06.2011 r.

82 Art. 18. 1. Do poświadczania tłumaczeń oraz poświadczania odpisów pism tłumacz przysięgły używa pieczęci, zawierającej w otoku jego imię i nazwisko, a w środku wskazanie języka, w zakresie którego ma uprawnienia oraz pozycję na liście tłumaczy przysięgłych, o której mowa w art. 6 ust. 2. Pieczęć zamawia, na koszt tłumacza przysięgłego, Minister Sprawiedliwości w Mennicy Państwowej. 2. Na wszystkich poświadczonych tłumaczeniach oraz poświadczonych odpisach pism, które wydaje tłumacz przysięgły, wymienia się pozycję, pod którą tłumaczenie lub odpis są odnotowane w repertorium. Na sporządzonych tłumaczeniach i odpisach pism należy stwierdzić, czy sporządzono je z oryginału, czy też z tłumaczenia lub odpisu oraz czy tłumaczenie lub odpis jest poświadczony i przez kogo.

83 Słowo „zaświadczone tłumaczenie” i ,zaświadczony odpis” zastąpiono zwrotami „poświadczone tłumaczenie” i ,poświadczony odpis”.

${ }^{84}$ Usunięto fragment: ,(np. zawiera ślady przeróbek)”.

${ }^{85}$ Kodeks został opracowany przez komitet redakcyjny, składający się z tłumaczy przysięgłych i przedstawicieli Ministerstwa Sprawiedliwości.
} 
zauważył Sędzia SN Jacek Gudowski ${ }^{86}$ wobec braku jednoznacznych normatywnych wytycznych pozwalających zdefiniować pojęcie „odpisu", należy sięgnąć do słownika języka polskiego, które jak wcześniej wspomniano, od lat określa „odpis” jako „tekst odpisany, kopię oryginału", czyli dokument stanowiący odwzorowanie lub odzwierciedlenie jego treści. Dlatego odpis może być sporządzony metodą tradycyjną, stosowaną od wieków, która polega na odpisaniu oryginału ręcznie lub mechanicznie (maszynowo) lub napisaniu go przez kalkę tworząc kopię. W uzasadnieniu tego postanowienia trafnie wyjaśniono jednak, że współcześnie, w związku z rozwojem poligrafii, zdecydowanie dominują proste techniki reprograficzne, pozwalające na multiplikację dokumentów - kserografia oraz wydruki komputerowe (obrazy tekstowe i graficzne), dlatego ,pod pojęciem odpisu należy rozumieć kopię jako formę, odmianę odpisu dokonanego metodą reprograficzną". Współcześnie nie „odpisuje” się już bowiem dokumentów, a wykonuje ich kopię przy pomocy wspomnianych urządzeń. Dodatkowo warto zauważyć, że wydanie w XXI wieku odpisów dokumentów urzędowych sporządzonych - „odpisanych” ręcznie czy przez kalkę lub nawet przepisanych maszynowo, budziłoby poważne wątpliwości urzędników co do wiarygodności tych dokumentów. Ustawodawca użył pojęcia „kopii” w Rozporządzeniu Ministra Sprawiedliwości z dnia 2 sierpnia 1982 r. (Dz. U. $1982 \mathrm{nr} 24$ poz. 174) w sprawie wynagrodzenia tłumaczy przysięgłych (i powielił go w kolejnych rozporządzeniach, aż do wejścia w życie przepisów obecnie obowiązujących), ale w znaczeniu kopii maszynopisu tłumaczenia, sporządzonego przez tłumacza. Ponadto w ostatnich latach wprowadzono pojęcie ,kopii” do wielu aktów prawnych, np. do Ustawy z dnia 14 lutego 1991 r. Prawo o notariacie (Dz.U.08.189.1158) oraz do Ustawy z dnia 17 listopada 1964 r. - Kodeks postępowania cywilnego (Dz.U. Nr 43, poz. 296). Również w językach obcych odpowiednikiem polskiego „odpisu” są słowa: ang. copy, hiszp. copia, fr. copie, niem. Kopie, ros. копия. Pojęcie „odpisu” wydaje się być więc archaizmem i winno być zastąpione słowem „kopia”.

\section{„Poświadczony odpis” w zawodzie tłumacza przysięgłego i notariusza}

Ustawa o zawodzie tłumacza przysięgłego weszła w życie w roku 2005 jako akt niezbędny do uchwalenia w kontekście przyjęcia Rzeczypospolitej Polskiej do Unii Europejskiej. W akcie tym, w art. 13, zawarto uprawnienia tłumacza przysięgłego, które pośrednio odpowiadają swoją treścią uprawnieniom określonym w Rozporządzeniu z 1968 roku: tłumacz uprawniony jest do ,....) sporządzania poświadczonych odpisów pism w języku obcym, sprawdzania i poświadczania odpisów pism, sporządzonych przez inne osoby (...)". Rozporządzenie Ministra Sprawiedliwości z dnia 24 stycznia 2005 roku w sprawie wynagrodzenia za czynności tłumacza przysięgłego (Dz. U. Nr 15, poz. 131), przewiduje natomiast $\mathrm{w} \S 4$ wynagrodzenie za sporządzenie poświadczonego odpisu pisma w języku obcym i określa je na 50 \% stawki przewidzianej za tłumaczenie na język polski. Z kolei za sprawdzenie i poświadczenie odpisu pisma rozporządzenie to przewiduje $30 \%$ stawki przewidzianej za tłumaczenie na język polski. Oba te akty będą stanowiły podstawę badań nad problematyką pojęcia ,poświadczonego odpisu” w zawodzie tłumacza przysięgłego.

\footnotetext{
${ }^{86}$ W uzasadnieniu do Postanowienia Sądu Najwyższego z dnia 27 stycznia 2006 roku III CK 369/05 (Orzecznictwo Sądu Najwyższego Izba Cywilna 2006/11/187)
} 
Wobec powyższego zasadne jest przeanalizowanie przedmiotowych uprawnień w zawodzie notariusza. W przepisie art. 96 i następnych ustawy Prawo o notariacie ustawodawca reguluje sporządzanie odpisów i poświadczanie za zgodność tych odpisów, jak wcześniej wspomniano, również sporządzonych w języku obcym. Z ustawy wynika, że notariusz poświadcza zgodność odpisu z okazanym dokumentem oraz że stwierdza on zgodność odpisu, wyciągu lub kopii z okazanym dokumentem. Uprawnienia notariusza nakładają się więc z uprawnieniami tłumacza przysięgłego. Jednocześnie Rozporządzenie Ministra Sprawiedliwości z dnia 28 czerwca 2004 r. w sprawie maksymalnych stawek taksy notarialnej (Dz. U. z dnia 29 czerwca 2004 r.) przewiduje w $§ 13$ wynagrodzenie za poświadczenie zgodności odpisu $\mathrm{z}$ okazanym dokumentem (czyli sporządzenie poświadczonej kopii), za każdą stronę w wysokości 6 zł. Ustawodawca przewiduje wynagrodzenie tłumacza przysięgłego za dokonanie dokładnie tej samej czynności, przykładowo w przypadku języka pozaeuropejskiego posługującego się alfabetem niełacińskim i ideogramami - 24, 77 zł za każdą stronę (50\% stawki przewidzianej za tłumaczenie na język polski). Warto wspomnieć, że przepis art. 16. 2 ustawy mówi, że „Minister Sprawiedliwości określi (...) stawki wynagrodzenia za czynności tłumacza przysięgłego (...) przy uwzględnieniu stopnia trudności i zakresu tłumaczenia”. W momencie powstawania pierwowzoru przepisu artykułu regulującego sporządzanie poświadczonych odpisów trudność wykonywanej czynności oraz nakład pracy tłumacza był rzeczywiście znacznie większy, czynność ta wymagała bowiem znajomości języka obcego oraz dysponowania odpowiednimi urządzeniami pisarskimi z alfabetem języka obcego, jednak w chwili obecnej sporządzenie poświadczonego odpisu (skserowanie i poświadczenie kopii) nie wymaga, jak przed laty, poświęcenia wielu godzin pracy, drogich materiałów ani nawet znajomości języka, stąd wniosek, że ustawodawca nie uwzględnił stopnia trudności tej czynności. Dodatkowo z uwagi na jednakowy nakład pracy notariusza i tłumacza przysięgłego, wynikający ze sporządzenia tego poświadczonego odpisu, taka rozbieżność w wynagradzaniu jest zupełnie nieuzasadniona. Podobne wątpliwości budzi również treść $§ 5$ Rozporządzenia Ministra Sprawiedliwości w sprawie wynagrodzenia za czynności tłumacza przysięgłego, które przewiduje wynagrodzenie za sprawdzenie i poświadczenie odpisu pisma sporządzonego w języku obcym przez inną osobę w wysokości $30 \%$ stawki przewidzianej za tłumaczenie na język polski. W praktyce nakład pracy przy sporządzeniu „odpisu”, czyli skserowaniu dokumentu przez samego tłumacza jest o wiele mniejszy, nie wymaga już bowiem sprawdzenia często częściowo nieczytelnego czy zniszczonego dokumentu, natomiast „odpis” sporządzony, czyli kserokopia wykonana przez osobę inną niż tłumacz przysięgły danego języka, wymaga dokładnego, często długotrwałego porównywania obu testów w celu starannego wykonania obowiązku poświadczenia odpisu. Dlatego otrzymanie wynagrodzenia w wysokości jedynie $30 \%$ jest w tym przypadku nieadekwatne do nakładu pracy w porównaniu do stawki za sporządzenie odpisu (za które tłumacz powinien pobrać aż $50 \%$ stawki - $\$ 4$ omawianego rozporządzenia). Wykonanie kopii przez samego tłumacza przysięgłego jest więc szybsze i mimo, iż teoretycznie możliwe jest poświadczanie odpisów (czyli kopii dokumentów) sporządzonych przez inne osoby, jednakże w praktyce zarówno notariusze jak i tłumaczenie przysięgli dokonują wszelkich kserokopii osobiście dla pewności ich zgodności z oryginałem. 


\section{Stosowanie pojęcia ,poświadczonego odpisu”}

Jak podkreśla Kodeks tłumacza przysięgłego, na tłumaczu przysięgłym w trakcie wykonywania uprawnień ciąży odpowiedzialność osoby zaufania publicznego. Funkcja tłumacza przysięgłego jest $\mathrm{w}$ pewnym zakresie zbliżona do funkcji notariusza, ponieważ tłumacz też poświadcza, że wykonane przez niego tłumaczenie jest zgodne $\mathrm{z}$ tekstem oryginalnym i że ponosi za to poświadczenie pełną odpowiedzialność. Instytucją uprawnioną do sporządzania poświadczonych odpisów (kopii) jest w Polsce notariusz, wykonujący swoje uprawnienia na podstawie ustawy Prawo o notariacie, przewidującej w art. 79 , że notariusz sporządza między innymi poświadczenia oraz odpisy dokumentów. Nie zastrzeżono jednak, jak w Ustawie o zawodzie tłumacza przysięgłego, w jakim języku powinny być te dokumenty sporządzone, nadając notariuszowi prawo poświadczania odpisów dokumentów we wszystkich językach świata. Współcześnie, poświadczanie odpisu dokumentu sporządzonego w języku obcym za zgodność z oryginałem nie polega już na „odpisywaniu” dokumentu i z uwagi na wszechobecność nowoczesnych urządzeń kopiujących, nie wymaga znajomości języka obcego przez notariuszy. W praktyce to właśnie notariusze poświadczają dokumenty sporządzone w jakimkolwiek języku, wykonując w ten sposób uprawnienia nadane jeszcze w 20-tych latach XX wieku tłumaczom przysięgłym. Trudno zgodzić się więc z komentarzem do tej regulacji, przedstawionym $\mathrm{w}$ książce wydanej $\mathrm{w}$ Warszawie 2010 roku pod redakcją B. Cieślika, L. Laski i M. Rojewskiego pt. Egzamin na ttumacza przysiegtego. Komentarz, teksty egzaminacyjne, dokumenty, który mówi, że „W zasadzie poświadczeń odpisów dokonuje notariusz (...). Trudno jednak wymagać od notariusza znajomości języków obcych pozwalającej mu na poświadczanie odpisów pism sporządzonych w tych językach, dlatego to zadanie powierzono właśnie tłumaczom przysięgłym" ${ }^{\text {" }}$. Współcześnie notariusz nie musi bowiem władać językiem obcym w celu sporządzenia i poświadczenia „odpisu”, jak również w praktyce nie poświadcza odpisów pism sporządzonych przez inną osobę. Z łatwością można zauważyć również, że tłumacze przysięgli nie sporządzają poświadczonych odpisów (kopii) dokumentów sporządzonych w języku obcym, jak również nie poświadczają odpisów dokumentów sporządzonych przez inne osoby, a urzędy w Polsce wymagają odpisów dokumentów poświadczonych przez notariusza. Ponadto zdecydowana większość tłumaczy przysięgłych, ustanowionych w czasach dostępności współczesnych technik kopiowania, nie rozumie i nie chce stosować pojęcia „odpisu”, przewidzianego w ustawie. Łatwo zaobserwować również brak literatury prawniczej dotyczącej nowych uregulowań zawodu tłumacza przysięgłego, która pomogłaby tłumaczom przysięgłym w zrozumieniu ich uprawnień, związanych z pojęciem „poświadczonego odpisu”. Jedyny, prócz wyżej powołanego, dostępny na rynku Komentarz do Ustawy o zawodzie ttumacza przysięgłego wydany w Warszawie w 2005 roku pod redakcją G. Dostatniego przewiduje jedynie, że „przepis art. 13 pkt. 2 ustawy upoważnia tłumacza przysięgłego do poświadczania odpisów pism w języku obcym, sporządzonych przez niego samego bądź inną osobę. W tym przypadku również nie ważne jest, kto sporządził dany odpis, ale kto go poświadcza" ${ }^{\text {. }}$. Nie

87 Cieślik B., Laska L., Rojewski M. (red.), Egzamin na ttumacza przysięgtego. Komentarz, teksty egzaminacyjne, dokumenty, Warszawa 2010, 46.

${ }^{88}$ Dostatni G. (red.), Komentarz do Ustawy o zawodzie ttumacza przysiętego, Warszawa 2005, 90. 
wyjaśnia on jednak czym jest sporządzenie poświadczonego odpisu oraz nie przewiduje

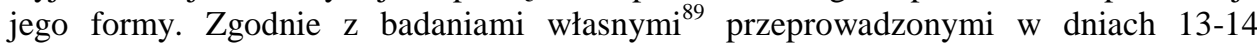
czerwca 2011 roku wśród zawodowych tłumaczy, 65,6 \% z nich uważa, że w praktyce „poświadczony odpis” oznacza „dodatkowy egzemplarz”, „wypis” lub „poświadczoną kopię tłumaczenia".

W praktyce zleceniodawcy, w tym sądy, prokuratury, Policja oraz organy administracji publicznej, podmioty prywatne i instytucje pozarządowe, nie zlecają tłumaczom przysięgłym sporządzania „poświadczonych odpisów”. Często zamawiane są natomiast „dodatkowe egzemplarze” tłumaczenia. Pojęcie „dodatkowych egzemplarzy” pojawia się co prawda w ustawie w art. 17 ust. 1 pkt. 4, który przewiduje, że repertorium zawiera liczbę sporządzonych egzemplarzy. Biuletyn TEPIS nr 71 Jesień 2009, Zima 2010 wyjaśnia, że dodatkowe egzemplarze mogą być wydawane „klientom prywatnym” i podlegają wpisowi do repertorium jako podstawa rozliczenia z fiskusem. Dodatkowo zalecano, aby taki egzemplarz, jeśli nie był wydany równocześnie z tłumaczeniem, odnotować pod nowym numerem repertorium wraz $\mathrm{z}$ nową datą ${ }^{90}$. Biuletyn nie przewiduje jednak rozwiązania w przypadku powołania tłumacza przysięgłego do sporządzenia dodatkowego egzemplarza przez inne, niż prywatne, podmioty. Nie proponuje również żadnego rozwiązania w zakresie pobieranego wynagrodzenia za te czynności. Poprzednie przepisy dotyczące uprawnień tłumaczy przysięgłych już od 1982 roku regulowały kwestię „,dodatkowego egzemplarza" "11. Rozporządzenie Ministra Sprawiedliwości z dnia 25 sierpnia 1986 r. w sprawie wynagrodzenia tłumaczy przysięgłych przewidywało w $§ 5$ ust. 1 ,W razie sporządzenia i zaświadczenia dodatkowych egzemplarzy tłumaczenia (...), wymagającym ponownego ich przepisania, wynagrodzenie wynosi $50 \%$ stawki przewidzianej jak za tłumaczenie (...)”. Natomiast w ust. 2 ustalono, że ,za sporządzenie i zaświadczenie kopii maszynopisu tłumaczenia (...), sporządzonego przez tłumacza, wynagrodzenie za każdą kopię wynosi $20 \%$ stawki przewidzianej za tłumaczenie (...)” - w obecnych czasach odpowiednikiem ,kopii maszynopisu" byłby wydruk wersji elektronicznej tłumaczenia. Wynagrodzenie, słusznie przyznane przez ustawodawcę w podanej wysokości było więc (do momentu wejścia w życie nowych przepisów) i byłoby do chwili obecnej, adekwatne do nakładu pracy i wysiłku tłumacza. Obecnie obowiązująca Ustawa o zawodzie tłumacza przysięgłego nie nadaje tłumaczowi przysięgłemu wprost uprawnień do wydawania dodatkowych egzemplarzy, a co za tym idzie Rozporządzenie w sprawie wynagrodzenia za czynności tłumacza przysięgłego nie przewiduje wynagrodzenia za wydanie dodatkowego egzemplarza. Dlatego też w praktyce stosowania ustawy „dodatkowym egzemplarzem” zarówno tłumaczenia sporządzonego w języku obcym jak i języku polskim, tłumacze nazywają właśnie ,poświadczony odpis” oraz stosują stawki wynagrodzenia, przewidziane dla sporządzenia odpisu, przy czym rażącą niezgodnością z prawem jest taka interpretacja przepisu, mimo, że zgodnie z art. 13 pkt. 2, tłumacz przysięgły uprawniony jest do sporządzania poświadczonych odpisów tylko i wyłącznie w języku obcym. Nakład pracy tłumacza przysięgłego w zakresie wydania „dodatkowego

\footnotetext{
${ }^{89} \mathrm{~W}$ ankiecie wypowiedziało się 74 zawodowych tłumaczy portalu globtra http://www.globtra.com/forum/index.php?topic=4965.0; viewResults, 13.06.2011 r.

${ }^{90}$ Kierzkowska D. (red), Biuletyn TEPIS nr 71 Jesień 2009, Zima 2010, Warszawa 2009, 34.

${ }^{91}$ Rozporządzenie Ministra Sprawiedliwości z dnia 2 sierpnia 1982 r. (Dz.U. 1982 nr 24 poz. 174).
} 
egzemplarza" jest nieadekwatny do wcześniej omówionego już wynagrodzenia. Organy państwowe respektują jednak tak sporządzone rachunki i wypłacają te nieadekwatne i stosunkowo wysokie wynagrodzenia jak za „odpisy”, mimo, że w zasadzie powinny skserować sporządzone tłumaczenie uwierzytelnione i samodzielnie poświadczyć je za zgodność z oryginałem. Tłumacz powinien bowiem odmówić wykonania czynności, do której wykonania nie jest uprawniony. Warto tutaj przytoczyć jednak, że przepis art. 15 omawianej ustawy odbiera tłumaczowi przysięgłemu prawo odmowy wykonania tłumaczenia na żądanie sądu, prokuratora, Policji oraz organów administracji publicznej $^{92}$. Dlatego też, $\mathrm{Z}$ uwagi na ewentualne utrudnienia $\mathrm{i}$ konsekwencje, czasochłonność postępowania wyjaśniającego, jak wyżej wspomniano „dodatkowy egzemplarz" traktowany jest jako „odpis” zarówno przez tłumaczy jak i organy państwowe i inne podmioty, będące zleceniodawcami. Również niektóre ambasady w Polsce (na przykład Ambasada Turecka w Warszawie) wymagają złożenia dwóch tłumaczeń uwierzytelnionych jednego dokumentu, przy czym wymagane są dwa tłumaczenia uwierzytelnione oryginalne, a nie kopia tłumaczenia poświadczona przykładowo przez notariusza czy inną instytucję, przy czym jedno tłumaczenie uwierzytelnione pozostaje $\mathrm{w}$ ambasadzie, a drugie zostaje wydane interesantowi $\mathrm{z}$ adnotacją ambasady. Warto również zauważyć, że sporządzenie przez notariusza poświadczonej kopii tłumaczenia (przekładu sporządzonego w języku obcym), która to czynność polega na dołączeniu do tej kopii klauzuli poświadczającej w języku polskim, powoduje konieczność ponownego zlecenia tłumaczowi przysięgłemu tłumaczenia na język obcy notarialnej klauzuli poświadczającej. Procedura ta jest nie tylko czasochłonna, ale pociąga za sobą również koszty, których to utrudnień można by było z łatwością uniknąc poprzez znany legislacyjne. Nieuregulowanie prawne zagadnienia wydawania dodatkowych egzemplarzy tłumaczeń, powoduje absurdalną sytuację, w której zleceniodawca, potrzebując dwóch egzemplarzy powinien zlecić dwukrotnie usługę tłumaczenia uwierzytelnionego. Ustawa nie zabrania bowiem wykonania tłumaczenia jednego dokumentu wielokrotnie i pobierania wynagrodzenia jak za tłumaczenie. Zleceniodawcy, z uwagi na znikomy nakład pracy tłumacza przysięgłego (wydrukowanie sporządzonego już dokumentu i poświadczenie) uważają jednak za niesłuszne i niesprawiedliwe pobieranie przez tłumacza wynagrodzenia w pełnej wysokości, dlatego tłumacze rejestrują te tłumaczenia jako „tłumaczenia” lub „odpisy” i pobierają wynagrodzenie w wysokości $50 \%$ stawki należnej za tłumaczenie. W związku z tym, powstaje problem rejestrowania tzw. „dodatkowych egzemplarzy” i nadawania im numerów repertorium tłumacza przysięgłego. Rejestrowanie dodatkowych egzemplarzy przez większość tłumaczy jako „odpisy” pod odrębnym numerem repertorium, nie odpowiada jednak rzeczywiście dokonanej czynności tłumacza przysięgłego. Z powodu trudności w interpretacji i stosowaniu przepisu art. 13 pkt. 2, pracownicy wydziałów prawnych urzędów wojewódzkich przeprowadzający kontrole repertorium tłumacza przysięgłego nie kwestionują sposobu rejestrowania dodatkowych egzemplarzy jako „poświadczonych odpisów” (sporządzonych zarówno w języku polskim jak i obcym), mimo ich niezgodności z obowiązującymi przepisami.

\footnotetext{
${ }^{92}$ Chyba, że zachodzą szczególnie ważne przyczyny uzasadniające odmowę.
} 


\section{Propozycje rozwiązań i wnioski końcowe}

Wprowadzając w życie Ustawę o zawodzie tłumacza przysięgłego ustawodawca pozbawił tłumacza przysięgłego uprawnień do sporządzania dodatkowych egzemplarzy, w praktyce wykonywanych przez thumaczy do dnia dzisiejszego, pozostawiając natomiast niewykorzystywane uprawnienie do sporządzania ,poświadczonych odpisów”. Przyjęte przez prawo w 1982 roku rozwiązanie, ustalające procentową (a nie kwotowa) stawkę za dodatkowy egzemplarz, w dobie wszechobecności nowoczesnych technik drukujących, nie byłoby słuszne - wydanie bowiem dodatkowego egzemplarza tłumaczenia sporządzonego w zakresie języka pozaeuropejskiego posługującego się alfabetem niełacińskim lub ideogramami nie wymaga większego nakładu pracy tłumacza przysięgłego niż sporządzenie dodatkowego egzemplarza przez tłumacza przysięłego najpopularniejszych języków, a dla tłumaczy przewidziano różne stawki wynagrodzenia za tłumaczenia $\mathrm{w}$ zależności od tzw. grupy językowej, przewidzianej w Rozporządzeniu Ministra Sprawiedliwości z dnia 24 stycznia 2005 r. w sprawie wynagrodzenia za czynności thumacza przysiegłego. Wynagrodzenie za wydanie dodatkowego egzemplarza, obliczane procentowo, byłoby różne w zależności od grupy języka, co powodowałoby szereg kontrowersji wśród tłumaczy przysięłych. W momencie obowiązywania poprzedniego rozporządzenia rozwiązanie to było zasadne - sporządzenie dodatkowego egzemplarza ręcznie czy w drodze sporządzenia kopii maszynopisu tłumaczenia było powiązane z nakładem pracy, wynikającym przede wszystkim z posługiwania się alfabetem innym niż łaciński.

Rozbieżności między przepisami ustawy a praktyką powodują oczywistą konieczność przeprowadzenia gruntownych zmian w zakresie uprawnień tłumacza przysięgłego. Warto sięgnąć do rozwiązań, przyjętych przez ustawę Prawo o notariacie, która przewiduje w art. 95., że „oryginały aktów notarialnych nie mogą być wydawane poza miejsce ich przechowywania", którym to miejscem jest archiwum notarialne ${ }^{93}$. Analogicznie zasadnym byłoby, gdyby tłumacz przysięły sporządzał jedno oryginalne tłumaczenie. Regulacje prawne mogłyby dopuszczać również archiwizację elektroniczną. Natomiast notariusz wydaje stronom na podstawie art. 79 pkt. 7 „wypisy”, przy czym zgodnie z art. 109. „wypis ma moc prawną oryginału”. Każdy wypis zapisywany jest przez notariusza pod odrębnym numerem repertorium i posiada wzmiankę o zgodności wypisu z oryginałem aktu i numerem pod jakim oryginalny akt został zarejestrowany w repertorium. Ponadto w nagłówku wypisu aktu notariusz zaznacza, że wydany dokument jest wypisem. Wypis stanowi dosłowne powtórzenie oryginału, $\mathrm{z}$ zastrzeżeniem, że poprawek i przekreśleń znajdujących się w oryginale nie należy zamieszczać w wypisie. Na końcu wypisu zaznacza się, komu i kiedy wypis wydano. Wypis podpisuje notariusz i opatruje pieczęcią. Jeżeli wypis posiada więcej niż jedną stronę to powinien być on ponumerowany, połączony, parafowany i spojony pieczęcią. Zgodnie z Rozporządzeniem w sprawie maksymalnych stawek taksy notarialnej $\S 12$ ust. 1. wynagrodzenie notariusza za wydanie tak sporządzonego wypisu

\footnotetext{
${ }^{93}$ Zgodnie z Rozporządzeniem Ministra Sprawiedliwości z dnia 12 kwietnia $1991 \mathrm{r}$. w sprawie prowadzenia ksiąg notarialnych oraz przekazywania na przechowanie dokumentów sądom rejonowym (Dz. U. z dnia 20 kwietnia 1991 r.) § 7. 1. (1) Notariusz przechowuje u siebie oryginały aktów, testamentów i protokołów, odpisy dokonanych protestów oraz księgi notarialne wymienione w $§ 1$ ust. 1 pkt 1 i 2, a także w $\S 6$ z okresu ostatnich dziesięciu lat; po upływie tego okresu przekazuje je do archiwum ksiąg wieczystych sądu rejonowego właściwego ze względu na siedzibę kancelarii.
} 
wynosi 6 złotych za każdą stronę $e^{94}$. Kwota ta rzeczywiście odpowiada nakładowi pracy przy sporządzaniu poświadczonych odpisów pism notariusza czy tłumacza przysięgłego.

Porównanie opisanego wyżej stanu faktycznego z rozwiązaniem przyjętym przez ustawodawcę $\mathrm{W}$ prawie o notariacie, prowadzi do wniosku, że nadanie uprawnień sporządzania „wypisów” tłumaczom przysięgłym, w zupełności regulowałoby sporne kwestie i rozwiązywałoby szereg trudności przedstawionych w niniejszym opracowaniu, odpowiadałoby potrzebom rynku i organów państwowych, regulowałoby kwestię wynagrodzenia tłumaczy za wydawanie ,dodatkowych egzemplarzy” (z właściwym uwzględnieniem nakładu ich pracy), a tym samym odciążyłoby budżet państwa, który w chwili obecnej pokrywa wysokie $50 \%^{95}$ koszty ,dodatkowych egzemplarzy”. W rzeczywistości bowiem tłumacze przysięgli pod nazwą „odpisu” wydają charakterystyczne dla notariuszy „wypisy”, a brak prawnego uregulowania tych czynności prowadzi do rozbieżności w zakresie ich formy, jak również sposobu rejestrowania w repertorium. Natomiast pozostawienie, wykonywanego obecnie wyłącznie przez notariuszy, uprawnienia tłumacza przysięgłego do „sporządzania poświadczonych odpisów pism w języku obcym, sprawdzania i poświadczania odpisów pism, sporządzonych w danym języku obcym przez inne osoby", powielonego z lat sześćdziesiątych XX wieku i od lat błędnie stosowanego przez tłumaczy przysięgłych, przysparza jedynie trudności w rozumieniu i stosowaniu aktów prawnych regulujących zawód tłumacza przysięłłego, a także sprzyja „omijaniu prawa” zarówno przez tłumaczy jak i przez zlecających.

\section{Bibliografia}

Cieślik B., Laska L., Rojewski M. (red.), Egzamin na tłumacza przysięgłego. Komentarz, teksty egzaminacyjne, dokumenty, Warszawa 2010.

Dostatni G. (red.), Komentarz do Ustawy o zawodzie ttumacza przysięgłego, Warszawa 2005.

Kodeks Ttumacza Przysięgłego - Uchwała Rady Naczelnej PT TEPIS z 31 marca 2005 r. opracowana przez Komitet Redakcyjny KTP z udziałem przedstawicieli Ministerstwa Sprawiedliwości, Warszawa 2005.

Karłowicz J., Kryński A., Niedźwiedzki W. (red.), Słownik języka polskiego, Warszawa 1904.

Kierzkowska D. (red), Biuletyn TEPIS nr 71 Jesień 2009, Zima 2010, Warszawa 2009.

Skorupka S., Anderska H., Łempijska Z. (red.), Mały słownik języka polskiego, Warszawa 1968.

Sobol E. (red.) Nowy stownik języka polskiego, Warszawa 2003.

\footnotetext{
${ }^{94}$ Za stronę uważa się tekst obejmujący nie mniej niż 25 wierszy.

${ }^{95}$ Stawki przewidzianej za tłumaczenie.
} 


\section{Akty prawne}

Postanowienie Sądu Najwyższego z dnia 27 stycznia 2006 roku III CK 369/05 (Orzecznictwo Sądu Najwyższego Izba Cywilna 2006/11/187).

Rozporządzenie Ministra Sprawiedliwości z dnia 7 sierpnia 1920 roku wydane w porozumieniu z Ministrem Skarbu Państwa w przedmiocie wynagrodzenia świadków, znawców i tłumaczów w postępowaniu karnem (Dz. U. Nr 75, poz. 515).

Rozporządzenie Ministra Sprawiedliwości z dnia 24 grudnia 1928 r. o tłumaczach przysięgłych (Dz. U. Nr 104, poz. 943).

Rozporządzenie Ministra Sprawiedliwości z dnia 31 stycznia 1930 r. o tłumaczach przysięgłych (Dz. U. Nr 5 poz. 46).

Rozporządzenie Ministra Sprawiedliwości z dnia 16 maja 1930 r. wydane w porozumieniu z Ministrem Skarbu o należnościach świadków, biegłych i tłumaczów w sprawach karnych (Dz. U. Nr 39 poz. 349).

Rozporządzeniem Ministra Sprawiedliwości z dnia 19 sierpnia 1968 roku w sprawie tłumaczy przysięgłych (Dz. U. Nr 35, poz. 244).

Rozporządzenie Ministra Sprawiedliwości z dnia 2 sierpnia 1982 r. w sprawie wynagrodzenia tłumaczy przysięgłych (Dz.U. $1982 \mathrm{nr} 24$ poz. 174).

Rozporządzenie Ministra Sprawiedliwości z dnia 25 sierpnia 1986 r. $\quad$ w sprawie wynagrodzenia tłumaczy przysięgłych (Dz.U. 1986 nr 33 poz. 168).

Rozporządzenie Ministra Sprawiedliwości z dnia 25 sierpnia 1986 r. w sprawie wynagrodzenia tłumaczy przysięgłych (Dz. U. Nr 33 poz. 168).

Rozporządzenie Ministra Sprawiedliwości z dnia 8 czerwca 1987 roku w sprawie biegłych sądowych i tłumaczy przysięgłych (Dz. U. Nr 18, poz. 112).

Rozporządzenie Ministra Sprawiedliwości z dnia 12 kwietnia 1991 r. w sprawie prowadzenia ksiąg notarialnych oraz przekazywania na przechowanie dokumentów sądom rejonowym (Dz. U. z dnia 20 kwietnia 1991 r.).

Rozporządzenie Ministra Sprawiedliwości z dnia 28 czerwca 2004 r. w sprawie maksymalnych stawek taksy notarialnej (Dz. U. z dnia 29 czerwca 2004 r.).

Rozporządzenie Ministra Sprawiedliwości z dnia 24 stycznia 2005 roku w sprawie wynagrodzenia za czynności tłumacza przysięgłego (Dz. U. Nr 15, poz. 131).

Ustawa z dnia 17 listopada 1964 r. - Kodeks postępowania cywilnego (Dz.U. Nr 43, poz. 296). Ustawa o zawodzie tłumacza przysięgłego z 25 listopada 2004 roku, (Dz. U. Nr 273 poz. 2702). Ustawa z dnia 14 lutego 1991 roku Prawo o notariacie (Dz.U.08.189.1158).

\section{Strony www}

http://isap.sejm.gov.pl/search.jsp

http://pl.wikipedia.org/wiki/Strona_g\%C5\%82\%C3\%B3wna 